\title{
POST-IR IRSL DATING OF K-FELDSPAR FROM LAST INTERGLACIAL MARINE TERRACE DEPOSITS ON THE KAMIKITA COASTAL PLAIN, NORTHEASTERN JAPAN
}

\author{
KAZUMI ITO ${ }^{1}$, TORU TAMURA ${ }^{1}$ and SUMIKO TSUKAMOTO ${ }^{2}$

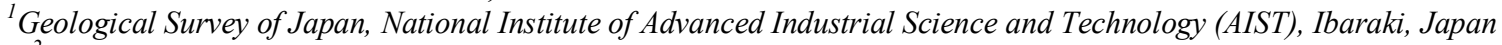 \\ ${ }^{2}$ Leibniz Institute for Applied Geophysics (LIAG), S3: Geochronology and Isotope Hydrology, Hannover, Germany
}

Received 26 December 2016

Accepted 8 September 2017

\begin{abstract}
To establish a suitable luminescence dating protocol for marine terrace deposits in Japan, we tested the applicability of K-feldspar post-infrared (IR) infrared stimulated luminescence (IRSL) (pIRIR) dating using a marine isotope stage (MIS) 5e terrace deposit from the Kamikita coastal plain (NE Japan), where independent age control from a tephra is available. One of the most commonly used pIRIR signals, measured at $290^{\circ} \mathrm{C}$ with the first IR stimulation temperature at $50^{\circ} \mathrm{C}\left(\mathrm{pIRIR}_{50 / 290}\right)$, faded with a mean $\mathrm{g}_{2 \text { days }}$ value of $1.94 \pm 0.19 \%$ /decade. In contrast, the pIRIR signal with a higher first IR stimulation temperature of $200^{\circ} \mathrm{C}\left(\mathrm{pIRIR}_{200 / 290}\right)$ had a much lower fading rate $\left(\mathrm{g}_{2 \text { days }}=\right.$ $0.16 \pm 0.49 \% /$ decade). The average fading-uncorrected and -corrected $\mathrm{pIRIR}_{200 / 290}$ ages of MIS $5 \mathrm{e}$ subtidal sediments obtained from two sampling sites were $126 \pm 3 \mathrm{ka}$ and $132 \pm 2 \mathrm{ka}$, which is in good agreement with the independent age control. We conclude that is it is now possible to use pIRIR protocol to estimate the ages of not only marine terraces formed during MIS 5 substages (5a, 5c) but also of older marine terraces, for which age evidence is limited.
\end{abstract}

Keywords: post-IR IRSL dating, K-rich feldspar, fading correction, marine terrace, MIS 5e.

\section{INTRODUCTION}

Late Pleistocene marine terraces formed during interglacial sea-level highstands are widely distributed across the Japanese islands. Tephrochronology has been used to correlate these terraces with marine isotope stages (MIS) (Machida and Arai, 2003). Ages of marine terraces formed during the last interglacial (MIS 5e; $123 \pm 7 \mathrm{ka}$ ) are well defined in many places (e.g., Koike and Machida, 2001) by widely distributed marker tephras. Marker tephras, such as Ontake Pm1 (On-Pm1, $95.7 \pm 5.3 \mathrm{ka}$, Aoki et al., 2008) and Toya (106 ka, Shirai et al., 1997; 112-115 ka, Machida and Arai, 2003;

Corresponding author: K. Ito

e-mail: kazumi-itou@aist.go.jp
$104 \pm 15 \mathrm{ka}$ to $118 \pm 15 \mathrm{ka}$, Ganzawa and Ike, 2011) in eastern Japan, and Aso-4 (86.8-87.3 ka, Aoki, 2008) and Sanbe-Kisuki (SK, 100-115 ka, Shiraishi et al., 1992) in western Japan (Machida and Arai, 2003), have helped to establish the chronology of these MIS 5e terraces. However, marker tephras are not always found in marine terrace deposits; thus, the chronology of marine terraces has often been determined by counting interglacial deposits backward from MIS 5e. The dating of marine terraces is particularly important for evaluating long-term vertical crustal movements, and a suitable, universally applicable age determination method for this purpose is desirable.

Optically stimulated luminescence (OSL) dating of quartz has been widely applied to date coastal and marine sediments (Jacobs, 2008). In Japan, Tanaka et al. (1997) successfully used the multiple-aliquot additive dose (MAAD) method to determine a quartz OSL age for a 
marine terrace on the Noto Peninsula corresponding to MIS 5e. Barreto et al. (2002) also used the MAAD quartz OSL method to successfully date marine terraces in northeastern Brazil formed during MISs 7 and 5e. Choi et al. (2003) dated marine terrace sediments on the Korean Peninsula by using the quartz single-aliquot regenerative dose (SAR) method and obtained ages ranging from $50 \mathrm{ka}$ to $70 \mathrm{ka}$, which are younger than the expected last interglacial age. The equivalent dose $\left(D_{e}\right)$ of the OSL signal, however, is commonly close to saturation in samples from the last interglacial period, except when the environmental dose rate is low (Murray and Funder, 2003; Pawley et al., 2008; Pascucci et al., 2014). K-feldspar displays higher dose saturation levels than quartz, so the K-feldspar SAR method is suitable for dating older sediments. Pedoja et al. (2006a, 2006b) used the SAR method to obtain infrared stimulated luminescence (IRSL) ages of feldspar from marine terraces in Ecuador and Peru. Because luminescence signals of feldspars are known to decrease after burial as a result of tunneling (anomalous fading) (Aitken, 1985), they corrected their ages for fading following Huntley and Lamothe (2001) and obtained fading-corrected ages corresponding to MISs $5 \mathrm{e}, 7$, and 9 .

Thomsen et al. (2008) found that the IRSL signal measured at an elevated temperature of $225^{\circ} \mathrm{C}$ after an initial low-temperature IRSL measurement at $50^{\circ} \mathrm{C}\left(\mathrm{IR}_{50}\right.$; the subscript refers to the measurement temperature) is much more stable (fades less) than the $\mathrm{IR}_{50}$ signal. This signal is called a post-IR IRSL (pIRIR) signal; hereafter, the first and second stimulation temperatures are shown as a subscript (e.g., pIRIR $50 / 225$ ). The pIRIR method effectively minimizes anomalous fading and has been applied to the determination of depositional ages older than the limit of quartz OSL age (e.g., Buylaert et al., 2009; Thiel et al., 2010, 2015; Kars et al., 2012). Moreover, pIRIR signals obtained at the higher measurement temperature of $290^{\circ} \mathrm{C}$ (pIRIR $50 / 290$; Thiel et al., 2011a, 2011b, 2012; Buylaert et al., 2012, 2013, 2015) and multiple elevated temperature (MET) pIRIR signals obtained at measurement temperatures higher than $250^{\circ} \mathrm{C}(\mathrm{Li}$ and $\mathrm{Li}, 2011$, 2012; Li et al., 2014) have been found to be more stable and often do not require anomalous fading correction. Buylaert et al. (2012) and Roberts (2012) suggested that low fading rates (g-value: $<1.0-1.5 \% /$ decade) may be an artifact of laboratory measurement, and that such rates may have a negligible effect on measured ages. Thiel et al. $(2012,2015)$ have used this sufficiently stable pIRIR $_{50 / 290}$ signal to determine the ages of marine terrace deposits. Thiel et al. (2012) demonstrated the feasibility of using the pIRIR ${ }_{50 / 290}$ protocol to determine the ages of marine terrace deposits as old as MIS 13 in Tunisia. Thiel et al. (2011a) assumed that no fading correction of pI$\mathrm{RIR}_{50 / 290}$ signals from fine-grained polymineral samples from tephric loess in Japan was needed. Additionally, Zander and Hilgers (2013) reported that the pIRIR $50 / 290$ signal is stable enough for a dose estimation even as high as $1600 \mathrm{~Gy}$, and they could determine ages as far back as the Brunhes-Matuyama reversal from fine polymineral grains from Lake El'gygytgyn, Siberia. Thiel et al. (2015) found that the pIRIR 50/225 signal from coarse-grained K-feldspar from the Oga Peninsula, northeastern Japan, displayed a non-negligible fading rate (1.3-2.3\%/decade), whereas Buylaert et al. (2012) showed that the pIRIR ${ }_{50 / 290}$ signal from the same material was sufficiently stable. Additionally, Thiel et al. (2015) showed that fadingcorrected pIRIR ${ }_{50 / 225}$ ages (corrected using the approach of Huntley and Lamothe, 2001) and uncorrected pIRIR $_{50 / 290}$ ages were consistent with one another and with independent age control.

In this study, we investigated pIRIR $_{290}$ signals obtained after different first IR stimulation temperatures from K-feldspar from marine terrace deposits in northeastern Japan that formed during the last interglacial. For each different first IR stimulation temperature, we measured $D_{e}$ values, dose recovery ratios, residual doses, and $\mathrm{g}$-values, and then calculated fading-uncorrected and -corrected ages. To select the most suitable signal, we then compared the pIRIR ages with ages of the marine terrace MIS5e reported by Miyauchi (1987) and Koike and Machida (2001). The age of MIS 5e is based on Lisiecki and Raymo (2005) (123 $\pm 7 \mathrm{ka})$.

\section{GEOLOGICAL SETTING AND SAMPLING}

\section{Kamikita coastal plain}

The Kamikita coastal plain, which lies along the Pacific coast at the northeastern end of Honshu Island, is about $50 \mathrm{~km}$ long and $30 \mathrm{~km}$ wide (Fig. 1). The plain has six marine terrace surfaces, named the Higher (Fukuromachi) (elevation, 110-220 m), Shichihyaku (90-110 m), Tengutai (45-80 m), Takadate $(30-40 \quad \mathrm{~m})$, Nejo $(10-15 \mathrm{~m})$, and Shibayama $(<10 \mathrm{~m})$ surfaces, and two levels of fluvial terraces, the Shichinohe and Sanbongi $(<5 \mathrm{~m})$ surfaces (Miyauchi, 1985, 1987; Koike and Machida, 2001). The northeastern part of the Kamikita plain is occupied by Lake Ogawara, an irregularly shaped body of water that is generally elongated parallel to the coast. Seaward of the lake, only the Takadate terrace and the two fluvial terraces have been mapped. The Holocene plain is distributed only along the rivers draining into the lake and the lake's outlet to the sea, and is not extensively developed along the modern shoreline.

The age of the Takadate terrace is constrained by the presence of the Toya tephra, which has been dated to $112-115$ ka by a combination of fission track dating, thermoluminescence (TL) dating, and stratigraphy (Machida and Arai, 2003), and to $104 \pm 15$ to $118 \pm 15 \mathrm{ka}$ by red TL dating (Ganzawa and Ike, 2011). Shirai et al. (1997) and Matsuura et al. (2014) reported that based on marine sediment core the Toya tephra was erupted during MIS $5 \mathrm{~d}(106 \mathrm{ka})$. The Toya tephra is found in the terrigenous upper part of the Takadate terrace deposits; thus, the underlying subtidal facies deposits are thought to 


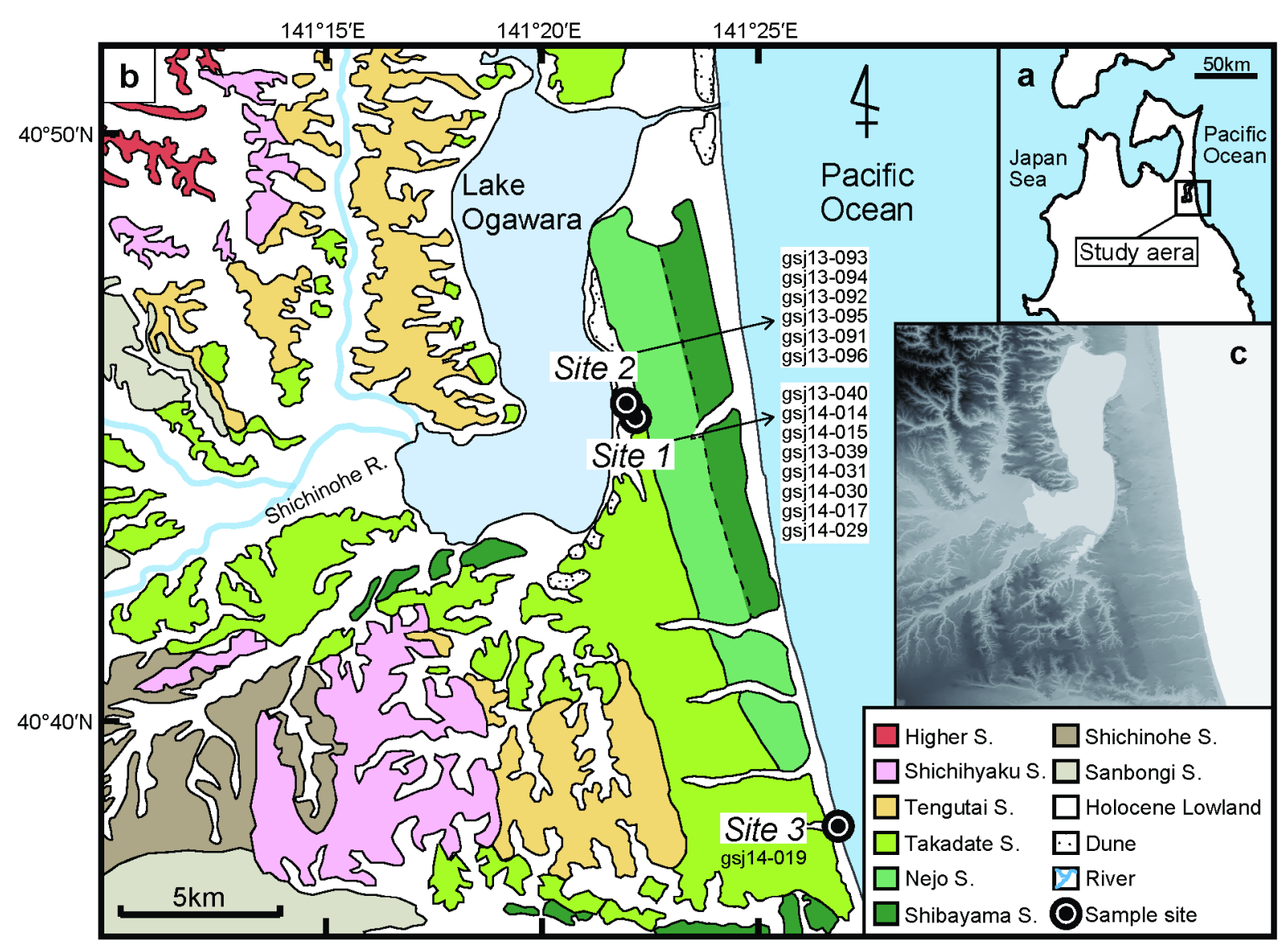

Fig. 1. (a) Location map of the Kamikita coastal plain, northeastern Japan. (b) Map showing the distribution of Late and Middle Pleistocene marine terraces and sampling sites (after Miyauchi, 1985, 1987). In the legend, surface is abbreviated as "S" The elevation range of each terrace is given in the text. (c) Digital elevation model of the Kamikita coastal plain based on 10-m-grid data from the Geospatial Information Authority of Japan. Lighter grays indicate lower elevations, and darker grays and black indicate higher elevations.

have formed during the last interglacial sea-level highstand $(123 \pm 7 \mathrm{ka})$. Although their ages are less well constrained, the Higher, Shichihyaku, and Tengutai terraces are presumed to have formed during older interglacial highstands, MIS 11, 9, and 7, respectively, whereas the Nejo (MIS 5c) and Shibayama (MIS 5a) terraces are younger than the Takadate terrace. Kuwabara (2009) correlated the Shichihyaku and Tengutai terraces with MIS 9 and 7, respectively, on the basis of phytolith evidence. The terrace sequence is thought to reflect both global sea-level changes and steady tectonic regional uplift caused by east-west horizontal compression during the Late Pleistocene (e.g., Miyauchi, 1985, 1987).

\section{Outcrops and sampling}

We investigated two outcrops (sites 1 and 2) at the landward edge of the Takadate terrace, facing Lake Ogawara (Fig. 1). Depositional facies of the outcrops were defined and interpreted based on sedimentary structures and grain size. The elevations of the facies boundaries were measured with a virtual reference station GPS
(Leica Viva GS08plus, Leica). These outcrops are $330 \mathrm{~m}$ apart and appear to expose laterally continuous deposits. The depositional succession beneath the Takadate terrace consists of lower subtidal facies and an upper terrigenous deposit, both of which were sampled. Light-tight black PVC tubes $15 \mathrm{~cm}$ long and $5 \mathrm{~cm}$ in diameter were hammered into the outcrop to sample sediment unexposed to light. Modern beach sand (sample gsj14-019) was collected at site 3 (Fig. 1) to determine the residual dose. This sample was obtained from $c a .10 \mathrm{~cm}$ depth by using the same type of tube.

\section{Site 1}

The subtidal facies at site 1 consists of fine to coarse sand containing granules and pebbles (Fig. 2). The lower part of the unit, $8 \mathrm{~m}$ thick, consists of cross-laminated gravelly coarse sand alternating with cross-laminated fine to medium sand. The coarse sand contains wave dunes and the fine sand contains burrows. This assemblage reflects the dominance of storm-wave sedimentation in the lower shoreface (Walker and Plint, 1992; Cummings 


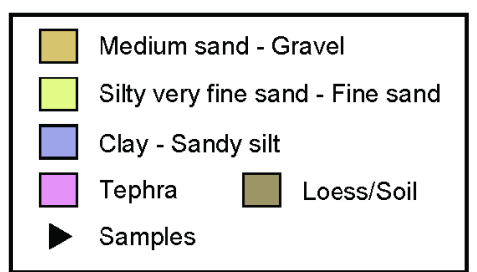

Site 1

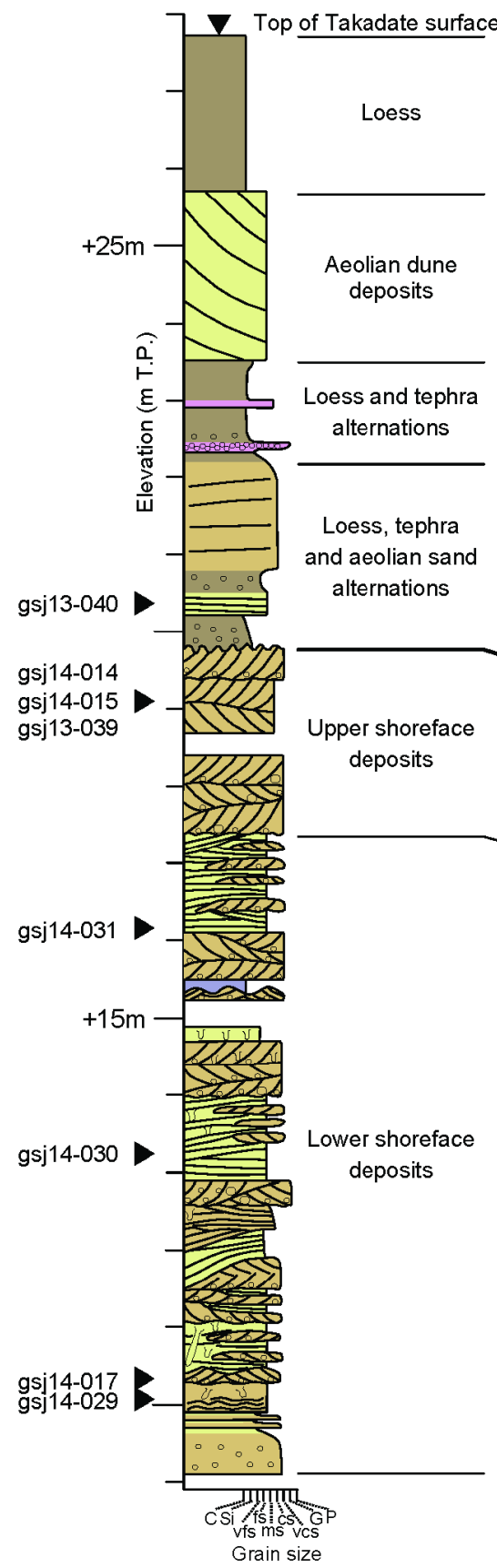

Site 2

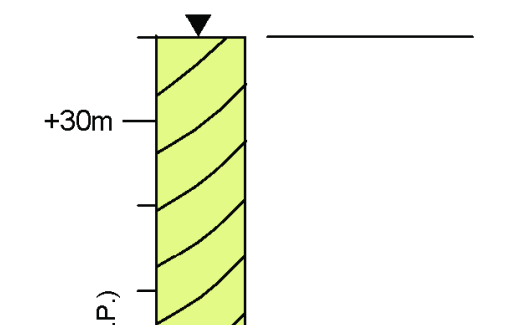


et al., 2009). The upper part of the unit, $2.5 \mathrm{~m}$ thick, is composed of trough cross-laminated coarse sand containing granules and pebbles, and it overlies the lower part of the unit with an erosional contact. The cross-lamination is indicative of the sedimentation of dunes in the upper shoreface (Clifton, 2006). The generally coarseningupward succession in the shallow-marine unit thus consists of regressive shoreface deposits (Walker and Plint, 1992). The erosional upper boundary of the unit at $19.8 \mathrm{~m}$ elevation implies that overlying deposits were removed from the upper shoreface and foreshore by erosion.

The terrigenous unit at site 1 consists of alternating sand and brownish silt. The silt layers are poorly sorted and contain sand and granules, and their brownish color indicates that they are loess beds or paleosols. A few unidentified tephra layers are intercalated with the silt layers. The sand layers are $30 \mathrm{~cm}$ to $200 \mathrm{~cm}$ thick and characterized by well-defined cross- to horizontal laminations. A 2-m-thick sand layer in the upper part of the unit exhibits aeolian dune stratification dipping eastward in the direction of the winter monsoon winds in this region. Other sand layers also probably represent aeolian dunes or sand sheets, because they are interbedded with paleosols.

We took four sediment samples for luminescence dating from different levels of the lower shoreface deposits (gsj14-017, gsj14-029, gsj14-030, and gsj14-031), three samples from one level of the upper shoreface deposits (gsj13-039, gsj14-014, and gsj14-015), and one sample from aeolian sand deposits (gsj13-040).

\section{Site 2}

The subtidal facies at site 2 consists of coarseningupward regressive shoreface deposits similar to those at site 1. Its erosional upper boundary is at $18.0 \mathrm{~m}$ elevation, suggesting slightly deeper erosion than at site 1 . The terrigenous unit, as at site 1 , is composed of aeolian sand and brownish paleosols, but its uppermost part is dominated by 9-m-thick aeolian dune deposits showing eastdipping cross-lamination. The same aeolian dune extends along the eastern shoreline of Lake Ogawara (Fig. 1; Miyauchi, 1985, 1987).

Samples for luminescence dating were taken from three levels of the lower shoreface deposits (gsj13-091, gsj13-095, and gsj13-096), from two levels of the upper shoreface deposits (gsj13-092 and gsj13-094), and from one level of the aeolian sand deposits (gsj13-093).

\section{Expected age of subtidal facies deposits}

The two subtidal facies, upper shoreface and lower shoreface, accumulated under different water depths and during different time periods and thus have different sedimentation ages. In Denmark, Fruergaard et al. (2015) confirmed that samples from subtidal facies are completely bleached by using OSL ages of Holocene samples, which increase with depth in direct correspondence to the sedimentation age of each sample. During the Holocene, the sedimentation rate of beach shorefaces has been rapid, with sedimentary successions $10-15 \mathrm{~m}$ thick forming in only 2000 years (e.g., Tamura et al., 2007). On longer Pleistocene timescales (e.g., $100 \mathrm{ka}$ ), a 2000-year age difference comprises only $2 \%$ of a sample's age. Thiel et al. (2015) illustrated a depth profile of pIRIR $_{50 / 225}$ ages of samples from subtidal facies (Thiel et al., 2015; their Fig. 13 ); in this profile, the pIRIR ${ }_{50 / 225}$ ages of samples from subtidal facies collected at heights $5 \mathrm{~m}$ to $25 \mathrm{~m}$ do not increase with depth. Therefore, we do not expect the ages of our samples from the subtidal facies to increase with depth but to concentrate at about $123 \pm 7 \mathrm{ka}$, the age of the MIS 5e sea-level highstand.

\section{SAMPLE PREPARATION, MEASUREMENT APPARATUS, AND DOSE-RATE CALCULATION}

All samples were processed and measured at the luminescence laboratory of the Geological Survey of Japan. Sediment within $3 \mathrm{~cm}$ from each end of the tube, which may have been exposed to sunlight during sampling, was removed and used for measuring moisture content and dosimetry. The remaining sediment was processed to extract coarse grains of K-rich feldspar. The samples were treated with $10 \% \mathrm{HCl}$ and $10 \% \mathrm{H}_{2} \mathrm{O}_{2}$ to dissolve carbonate and organic matter, respectively, and then screened using $180 \mu \mathrm{m}$ and $250 \mu \mathrm{m}$ mesh sieves. Finally, the K-rich feldspar fraction $\left(\rho=2.53-2.58 \mathrm{~g} / \mathrm{cm}^{3}\right.$; Aitken, 1998) was isolated by using sodium polytungstate. The feldspar grains were then mounted in aliquots with a diameter of $8.0 \mathrm{~mm}$ by using silicone oil on stainless steel disks with a diameter of $9.8 \mathrm{~mm}$.

Luminescence signals were measured with a TL-DA-20 automated Risø reader equipped with infrared LEDs for stimulation $\left(145 \mathrm{~mW} / \mathrm{cm}^{2}\right.$; central wavelength, $870 \mathrm{~nm}$ ) and a ${ }^{90} \mathrm{Sr} /{ }^{90} \mathrm{Y}$ beta source (dose rate, $c a$. $0.19 \mathrm{~Gy} / \mathrm{s}$ ) for laboratory irradiation, which was calibrated by using stainless steel and $180-250 \mu \mathrm{m}$ calibration quartz from Risø. Emissions in the blue-violet region, which are dominantly K-feldspar emissions (Huntley et al., 1991), were measured through Schott BG3 (thickness, $3 \mathrm{~mm})$, BG39 (2 mm), and GG400 (3 mm) filters.

The contributions of natural radioisotopes and cosmic radiation were considered in the determination of the annual dose rate. After mixing and homogenization of the dried sample, radioisotope concentrations were measured by inductively coupled plasma mass spectrometry and converted to dose rates by using the conversion factors of Guérin et al. (2011) (Table 1). The uncertainty of the radioisotope concentrations was assumed to be $\pm 5 \%$. Water content was estimated from the mean of the natural and saturated water contents and expressed as weight of water / weight of dry sediment, with a $\pm 5 \%$ uncertainty. The saturated water content of $31.0 \%$ was calculated from the mean saturated water content of four samples (gsj13-039, gsj13-040, gsj13-093, and gsj13-094) and 
K. Ito et al.

Table 1. Radioisotope concentration, water content, cosmic ray and dose-rate for sediment samples. Listed water content was natural value. The water content for dose rate calculation was estimated from the mean of natural and saturated (31.0\%) water contents. For details see main text.

\begin{tabular}{|c|c|c|c|c|c|c|c|c|}
\hline \multirow{2}{*}{ Sample } & \multirow{2}{*}{$\begin{array}{l}\text { Depth } \\
\text { (m) }\end{array}$} & \multicolumn{4}{|c|}{ Radioisotope concentraion } & \multirow{2}{*}{$\begin{array}{l}\text { Water } \\
\text { Content } \\
(\%)\end{array}$} & \multirow{2}{*}{$\begin{array}{c}\text { Cosmic } \\
\text { Dose Rate } \\
\text { (Gy/ka) }\end{array}$} & \multirow{2}{*}{$\begin{array}{c}\text { Dose-rate } \\
\text { (Gy/ka) }\end{array}$} \\
\hline & & K (\%) & $\mathrm{Rb}(\mathrm{ppm})$ & Th (ppm) & $U$ (ppm) & & & \\
\hline \multicolumn{9}{|l|}{$\overline{\text { Site } 1}$} \\
\hline gsj13-040 & 7.40 & $0.62 \pm 0.06$ & $20.8 \pm 2.1$ & $1.35 \pm 0.14$ & $0.38 \pm 0.04$ & 3.0 & 0.10 & $1.57 \pm 0.12$ \\
\hline gsj14-014 & 8.30 & $0.68 \pm 0.07$ & $23.2 \pm 2.3$ & $1.55 \pm 0.16$ & $0.44 \pm 0.04$ & 7.3 & 0.09 & $1.62 \pm 0.12$ \\
\hline gsj14-015 & 8.30 & $0.72 \pm 0.07$ & $23.1 \pm 2.3$ & $1.85 \pm 0.19$ & $0.48 \pm 0.05$ & 9.3 & 0.09 & $1.67 \pm 0.12$ \\
\hline gsj13-039 & 8.30 & $0.77 \pm 0.08$ & $19.9 \pm 2.0$ & $1.60 \pm 0.16$ & $0.44 \pm 0.04$ & 11.3 & 0.09 & $1.67 \pm 0.12$ \\
\hline gsj14-031 & 11.54 & $0.83 \pm 0.08$ & $24.9 \pm 2.5$ & $1.67 \pm 0.17$ & $0.52 \pm 0.05$ & 16.1 & 0.07 & $1.70 \pm 0.12$ \\
\hline gsj14-030 & 14.47 & $0.88 \pm 0.09$ & $24.1 \pm 2.4$ & $2.09 \pm 0.21$ & $0.60 \pm 0.06$ & 20.2 & 0.06 & $1.75 \pm 0.12$ \\
\hline gsj14-017 & 17.60 & $0.69 \pm 0.07$ & $23.1 \pm 2.3$ & $2.46 \pm 0.25$ & $0.46 \pm 0.05$ & 15.7 & 0.04 & $1.60 \pm 0.11$ \\
\hline gsj14-029 & 17.61 & $0.78 \pm 0.08$ & $22.9 \pm 2.3$ & $2.34 \pm 0.23$ & $0.74 \pm 0.07$ & 24.1 & 0.04 & $1.69 \pm 0.12$ \\
\hline \multicolumn{9}{|l|}{ Site 2} \\
\hline gsj13-093 & 11.84 & $0.50 \pm 0.05$ & $19.2 \pm 1.9$ & $1.63 \pm 0.16$ & $0.46 \pm 0.05$ & 11.4 & 0.07 & $1.44 \pm 0.10$ \\
\hline gsj13-094 & 13.80 & $0.52 \pm 0.05$ & $18.0 \pm 1.8$ & $1.30 \pm 0.13$ & $0.37 \pm 0.04$ & 11.2 & 0.06 & $1.41 \pm 0.10$ \\
\hline gsj13-092 & 14.08 & $0.71 \pm 0.07$ & $25.5 \pm 2.6$ & $1.93 \pm 0.19$ & $0.58 \pm 0.06$ & 17.7 & 0.06 & $1.61 \pm 0.11$ \\
\hline gsj13-095 & 16.07 & $0.69 \pm 0.07$ & $24.9 \pm 2.5$ & $1.82 \pm 0.18$ & $0.52 \pm 0.05$ & 19.2 & 0.05 & $1.57 \pm 0.11$ \\
\hline gsj13-091 & 17.33 & $0.55 \pm 0.06$ & $22.1 \pm 2.2$ & $1.80 \pm 0.18$ & $0.47 \pm 0.05$ & 10.3 & 0.05 & $1.48 \pm 0.11$ \\
\hline gsj13-096 & 18.03 & $0.73 \pm 0.07$ & $24.3 \pm 2.4$ & $1.94 \pm 0.19$ & $0.54 \pm 0.05$ & 18.7 & 0.04 & $1.60 \pm 0.11$ \\
\hline \multicolumn{9}{|l|}{ Site 3} \\
\hline gsj14-019 & 0.10 & $0.18 \pm 0.02$ & $6.2 \pm 0.6$ & $0.79 \pm 0.08$ & $0.22 \pm 0.02$ & 5.9 & 0.21 & $1.50 \pm 0.10$ \\
\hline
\end{tabular}

used for all samples. The $\alpha$-dose and $\beta$-dose attenuation factors were taken from Bell (1980) and Mejdahl (1979), respectively. The relative alpha efficiency (a-value) of Krich feldspar was set to $0.15 \pm 0.05$, as assumed by Balescu and Lamothe (1994). The size of the K-feldspar grains was determined to be $221 \pm 6 \mu \mathrm{m}$ by a CAMSIZER apparatus (Retsch Technology). The K content of the feldspar was assumed to be $12.5 \pm 0.5 \%$ (Huntley and Baril, 1997). The internal $U$ and Th contents were assumed to be zero. No internal $\alpha$-dose rate contribution from $\mathrm{U}$ and $\mathrm{Th}$ was considered, referred to the data set shown in Duller (1992). The cosmic dose rate was estimated following Prescott and Hutton (1994).

\section{LUMINESCENCE CHARACTERISTICS}

\section{Equivalent dose measurement and procedural tests}

Using gsj13-039 and gsj13-094, we investigated the characteristics of pIRIR 290 signals with different first IR stimulation temperatures. The pIRIR stimulation temperature and preheat temperature were fixed at $290^{\circ} \mathrm{C}$ and $320^{\circ} \mathrm{C}$, while the first IR stimulation temperature was varied between $50^{\circ} \mathrm{C}$ and $250^{\circ} \mathrm{C}$ with a $50^{\circ} \mathrm{C}$ increment. The luminescence signal was measured in 0.1 -s bins. The decay curves of the five pIRIR signals from gsj13-039 are shown in Fig. 3a. The highest intensity was that of the pIRIR $_{50 / 290}$ signal at $c a .11,000$ counts in the first $0.1 \mathrm{~s}$, while the pIRIR $250 / 290$ signal intensity was only $c a$. 400 counts in the first $0.1 \mathrm{~s}$.

Buylaert et al. (2012) performed a first IR stimulation temperature plateau test to check the dependency of pI$\mathrm{RIR}_{290} D_{e}$ values on the first stimulation temperature. Here, we also applied the pIRIR SAR protocol with dif- ferent first stimulation temperature for our samples to determine $D_{e}$ (Table 2; e.g., Buylaert et al., 2012; Yi et al., 2016). To construct a dose-response curve, the intensities were derived from the integral of the first $2.0 \mathrm{~s}$ (20 channels) after subtracting the average intensity during the last $20 \mathrm{~s}$. The Analyst Version 4.31 .9 (Duller, 2016) was used to calculate each $D_{e}$. The $D_{e}$ at each stimulation temperature was determined by calculating the arithmetic mean and standard error of the aliquots (Fig. $3 b)$. Most $D_{e}$ values plotted around the average, except at the first IR stimulation temperature of $250^{\circ} \mathrm{C}$ for gsj13-039, which showed a large scatter.

A dose recovery test was performed using at least six aliquots from each sample. Aliquots were exposed for $3 \mathrm{~h}$ to artificial sunlight in a UVACUBE 400 chamber (Hönle) with a SOL 500 lamp module at a lamp-to-

Table 2. Single aliquot regenerative (SAR) protocol used for $D_{e}$ measurements.

\begin{tabular}{|c|c|}
\hline Step & Measurement Protocol \\
\hline$\overline{1}$ & Give dose \\
\hline 2 & Preheat $320^{\circ} \mathrm{C}$ for $60 \mathrm{~s}$ \\
\hline 3 & IRSL $50,100,150,200,250^{\circ} \mathrm{C}$ for $200 \mathrm{~s}$ \\
\hline 4 & 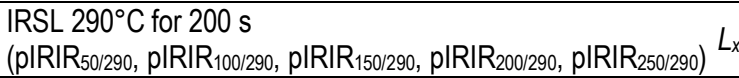 \\
\hline 5 & Give test dose \\
\hline 6 & Preheat $320^{\circ} \mathrm{C}$ for $60 \mathrm{~s}$ \\
\hline 7 & IRSL $50,100,150,200,250^{\circ} \mathrm{C}$ for $200 \mathrm{~s}$ \\
\hline 8 & 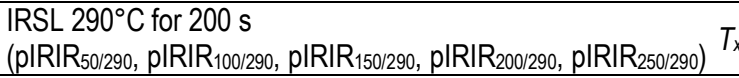 \\
\hline 9 & Hot IR bleach for $200 \mathrm{~s}$ at $325^{\circ} \mathrm{C}$ \\
\hline 10 & Return to step 1 \\
\hline
\end{tabular}


sample distance of $50 \mathrm{~cm}$. After this bleaching, half of the aliquots were given a dose of $\beta$-radiation nearly equal to each $D_{e}$ value and then analyzed, and the remaining aliquots were directly measured to estimate the residual dose. These residual dose values were subtracted from the recovered doses. The arithmetic means of the dose recovery ratio and residual doses were calculated, and the uncertainty was represented as one standard error. The data are shown in Fig. 3c. The dose recovery ratios plotted
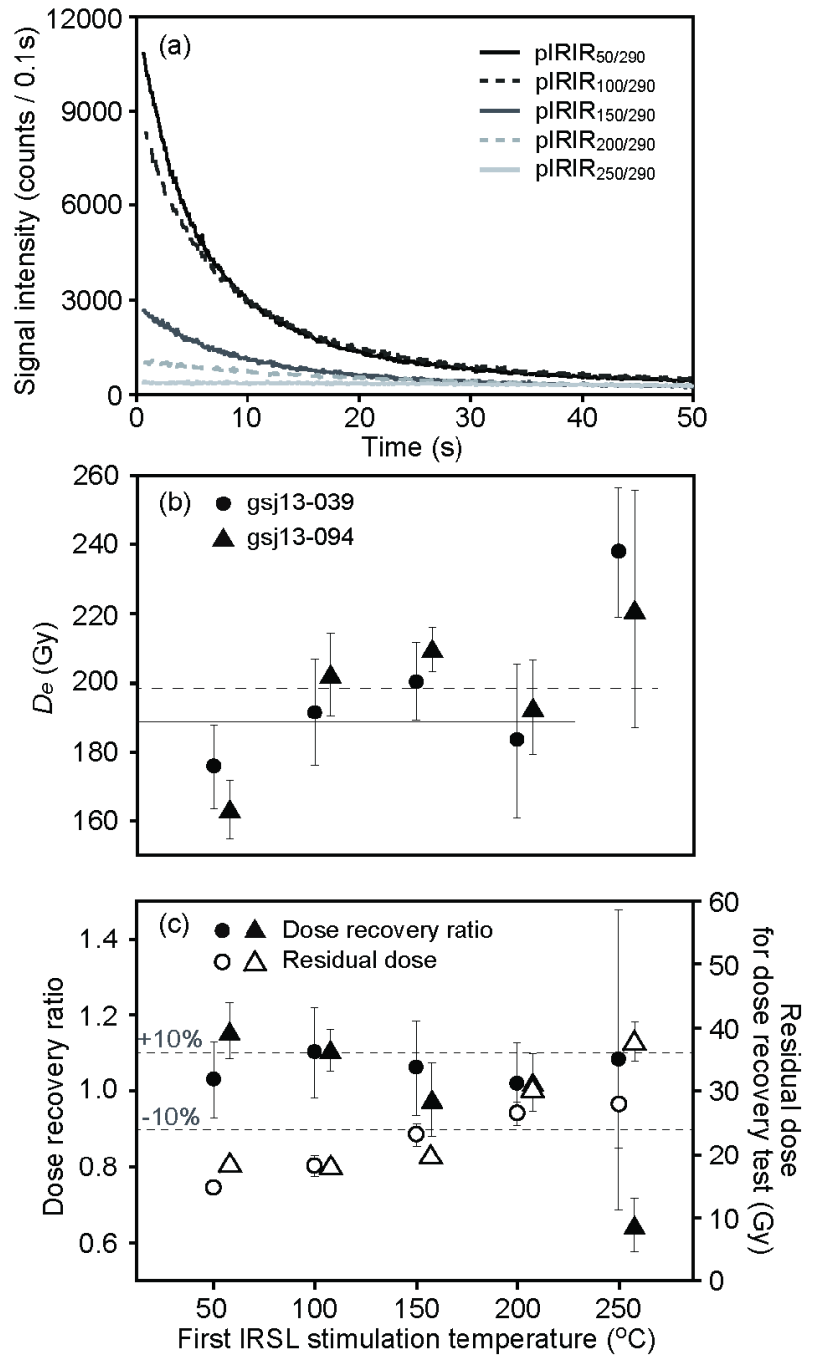

Fig. 3. pIRIR signal characteristics of samples gsj13-039 and gsj13-094 with different first IR stimulation temperatures. The pIRIR stimulation and preheat temperatures were fixed at 290 and $320^{\circ} \mathrm{C}$, respectively. (a) Typical signal intensities of pIRIR 290 signals from sample gsj13-039, (b) first IR stimulation temperature plateau, and (c) dose recovery ratio and residual dose after bleaching for $3 h$ with different first stimulation temperatures. The error bars show one standard error. In (b), the bold and dashed lines represent the average $D_{e}$ of each sample, except for $D_{e}$ at the first IR measurement temperature of $250^{\circ} \mathrm{C}$ for gsj13-039. In (c), the dashed lines represent the $\pm 10 \%$ range. within $\pm 10 \%$ from unity, except at the first IR stimulation temperature of $250^{\circ} \mathrm{C}$ for gsj13-094.

\section{Anomalous fading measurement}

It has been suggested that the fading of the pIRIR 290 signal is negligible in nature, because in very old samples measured by some studies the natural signal was close to the saturation level (Buylaert et al., 2011; Kars et al., 2012; Thiel et al., 2011b; Thomsen et al., 2011). Stability of the pIRIR 290 signal has also been inferred from age comparisons with an independent age control (Thiel et al., 2011a; 2015; Zander and Hilgers, 2013). However, in these previous studies, the fading rates of the samples were around 1-1.5\%/decade (Buylaert et al., 2012; Thiel et al., 2011b), and it was argued that the measured laboratory fading might be an artifact of the measurement procedure (Buylaert et al., 2012). On the other hand, Li and $\mathrm{Li}$ (2012) reported that the fading of the pIRIR $50 / 290$ signal was not negligible in their samples having a natural $D_{e}$ range from 250 Gy to $700 \mathrm{~Gy}$, but that fading of pI$\mathrm{RIR}_{200 / 290}$ signal was negligible.

In this study, we performed a fading test with different first IR stimulation temperatures using gsj13-039 and gsj13-094 to check the signal stability of our samples (Fig. 4). Additionally, for gsj13-040, gsj13-030, gsj13-093, and gsj13-095, we performed a fading test for pIRIR 290 with first stimulation temperatures of $50^{\circ} \mathrm{C}$ and $200^{\circ} \mathrm{C}$ (Table 3). Our fading test protocol was based on Auclair et al. (2003). Following the dose (ca. $140 \mathrm{~Gy}$ ) and preheating, the delay times were between $0.3 \mathrm{~h}$ and $96 \mathrm{~h}$, and the g-values were calculated following Huntley and Lamothe (2001). To express the g-value, the arbitrary time $\left(\mathrm{t}_{\mathrm{c}}\right)$ was normalized to 2 days $\left(\mathrm{g}_{2 \text { days }}\right)$. The data consisted of about 10 points from each sample, and the uncertainty is reported as one standard error. An example is shown in Fig. 4a. For all samples, the g-values of the pIRIR $_{50 / 290}$ and pIRIR $_{200 / 290}$ signals ranged from $1.25 \pm 0.66 \% /$ decade to $2.53 \pm 0.31 \% /$ decade and from $1.34 \pm 0.57 \% /$ decade to $1.57 \pm 0.40 \% /$ decade, respectively. The g-values of the pIRIR $50 / 290$ signal were larger than those of the pIRIR $200 / 290$ signal. For other signals, most gvalues decreased when the first IR stimulation temperature was higher (Fig. 4b). The data were also used to calculate the dimensionless recombination center density $\rho$ ' (Huntley, 2006), summarized in Table 3 for the fading correction following Kars et al. (2008).

\section{Residual dose estimation}

It is well known that the pIRIR signal is much more difficult to bleach than the $\mathrm{IR}_{50}$ signal (e.g., Buylaert et al., 2012; Kars et al., 2014; Sohbati et al., 2012). Additionally, Reimann et al. (2015) showed that different pIRIR stimulation temperatures have different rates of bleaching under daylight exposure. In bleaching experiments conducted by these previous studies, the pIRIR signal intensity did not reach an unbleachable residual 


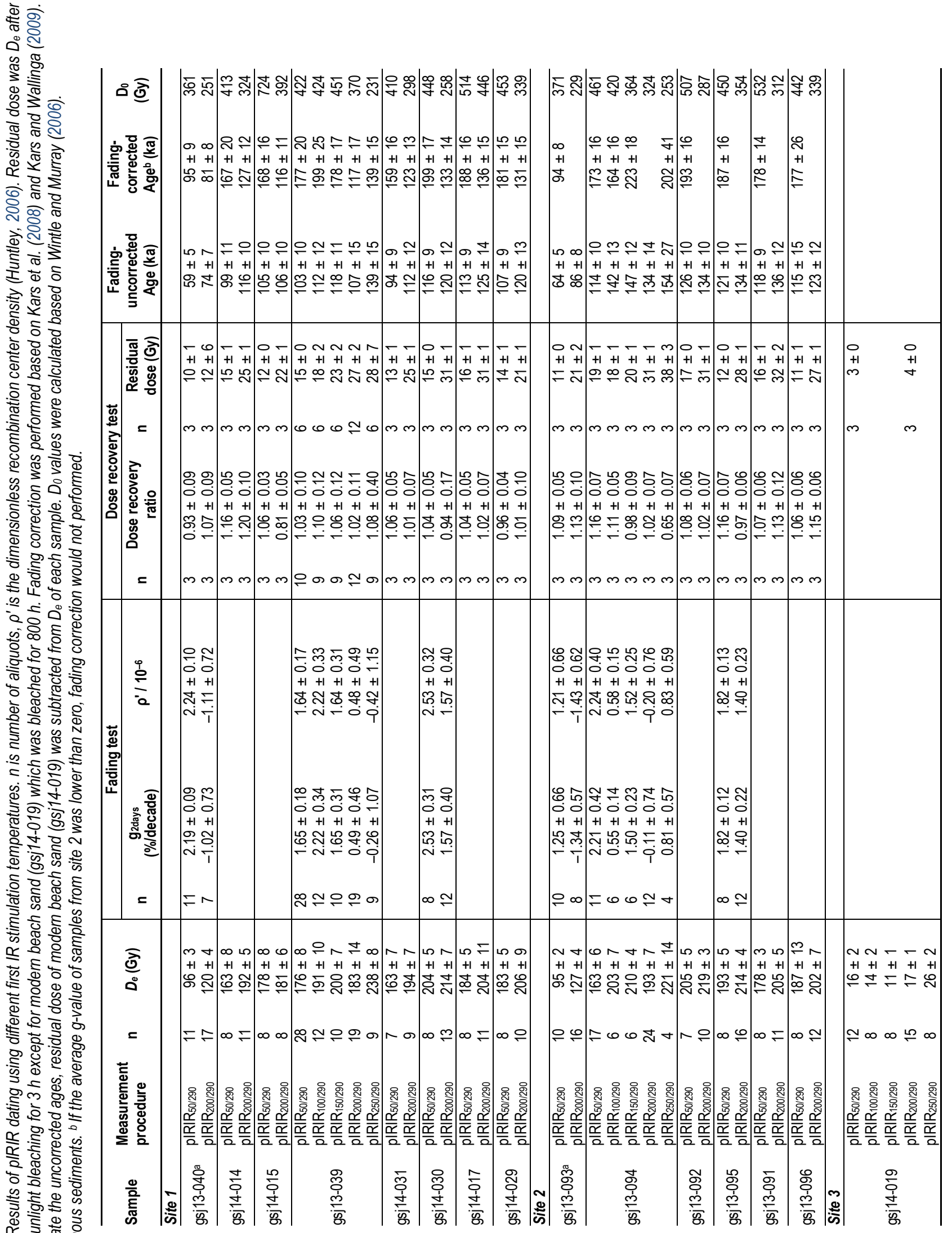

๘ क

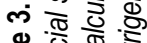

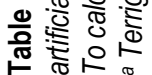



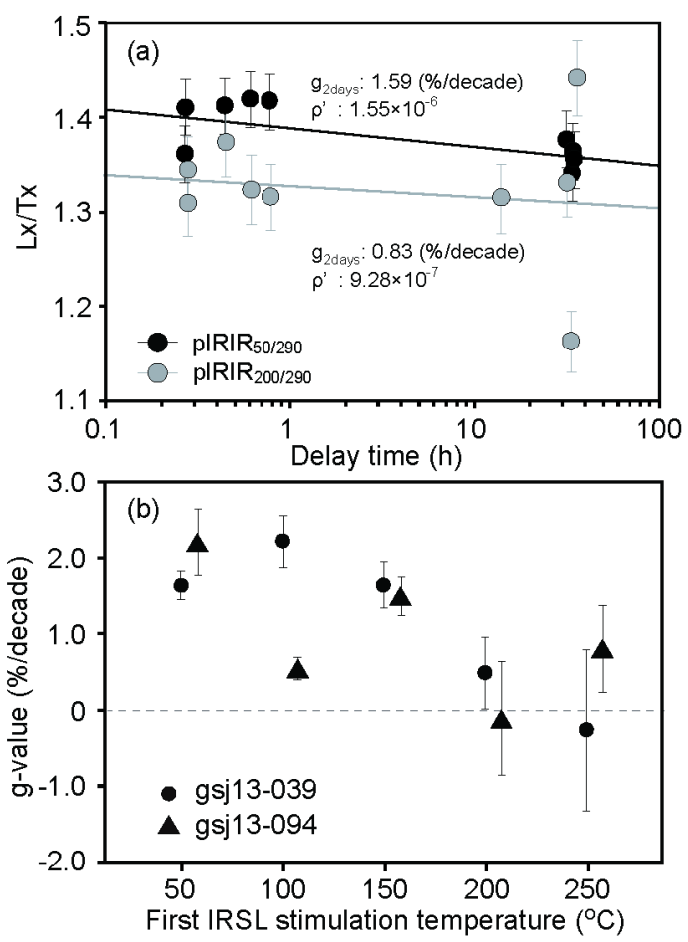

Fig. 4. Fading test results. (a) Typical results for sample gsj13-039; (b) g-values obtained with different first IR stimulation temperatures for gsj13-039 and gsj13-094. The error bars show one standard error.

level. However, Yi et al. (2016) recently showed that the residual dose of the pIRIR $50 / 290$ signal reached a lower limit after artificial sunlight (SOL2) bleaching for $300 \mathrm{~h}$, and its residual dose was $6.2 \pm 0.7 \mathrm{~Gy}$. In this study, the $D_{e}$ of the pIRIR $50 / 290$ signal of modern beach sand (gsj14-019) was $16 \pm 2$ Gy (Table 3), a much larger value than that of modern beach sand from Oga Peninsula (4.0 \pm 0.2 Gy, Buylaert et al., 2012). Since the bleaching of gsj14-019 may have been incomplete, aliquots were bleached under artificial sunlight for longer than $300 \mathrm{~h}$ with a maximum bleaching time of $800 \mathrm{~h}$. Sample aliquots were measured using the pIRIR $_{50 / 290}$ and pI$\mathrm{RIR}_{200 / 290}$ protocols, and the residual dose at each bleaching time was calculated as the average of at least six aliquots with an uncertainty of one standard error (Fig. 5). The pIRIR ${ }_{50 / 290}$ and $\operatorname{pIRIR}_{200 / 290} D_{e}$ values before bleaching, which were $15.7 \pm 1.8$ and $17.3 \pm 1.0 \mathrm{~Gy}$, respectively, decreased to $2.8 \pm 0.2$ and $3.9 \pm 0.2 \mathrm{~Gy}$, respectively, after $800 \mathrm{~h}$ of bleaching. These remaining $D_{e}$ values were assumed to be the unbleachable residual doses, and they were subtracted from all $D_{e}$ values used to calculate the pIRIR ${ }_{50 / 290}$ and pIRIR $200 / 290$ ages (Table 3 ). For other signals, residual doses after $3 \mathrm{~h}$ of bleaching in the dose recovery test increased with the first IR stimulation temperature (Fig. 3c). This result indicates that the bleachability of the pIRIR 290 signal decreases as the first stimulation temperature increases. Therefore, the residual

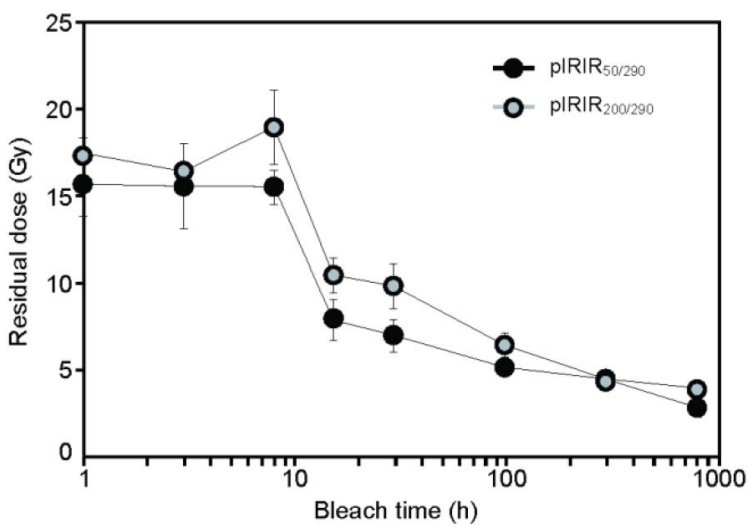

Fig. 5. Average residual dose obtained for different artificial sunlight bleaching times. Each data point represents the average of at least six aliquots. The error bars show one standard error.

doses of the pIRIR $100 / 290$, pIRIR ${ }_{150 / 290}$, and $\operatorname{pIRIR}_{250 / 290}$ signals were inferred by linear interpolation and extrapolation of the pIRIR ${ }_{50 / 290}$ and pIRIR $_{200 / 290}$ signals. The assumed residual doses and errors of the pIRIR $100 / 290$, pIRIR $_{150 / 290}$, and pIRIR $_{250 / 290}$ signals were $3.2 \pm 0.2$, $3.5 \pm 0.2$, and $4.3 \pm 0.2 \mathrm{~Gy}$, respectively.

\section{AGES AND DISCUSSION}

\section{Fading-uncorrected (residual-subtracted) ages}

The fading uncorrected ages obtained with different first IR stimulation temperatures from gsj13-039 and gsj13-094 are shown in Fig. 6a and Table 3, and those of the pIRIR ${ }_{50 / 290}$ and pIRIR $_{200 / 290}$ signals from the samples from the subtidal facies deposits are shown in Fig. 7. The uncorrected ages of gsj13-039 with different first IR stimulation temperatures are generally consistent with the expected age (MIS 5e, $123 \pm 7 \mathrm{ka}$ ), with a possible exception of the pIRIR ${ }_{50 / 290}$ signal (Fig. 6a). On the other hand, the uncorrected gsj13-094 ages of pIRIR $100 / 290$, pIRIR $_{150 / 290}$ and pIRIR $250 / 290$ signals are slightly older than the expected age if we do not consider the large scatter of own age. The uncorrected ages of the pIRIR ${ }_{200 / 290}$ signals of all samples (Fig. 7) were concordant with the expected age. The uncorrected ages of the pIRIR ${ }_{50 / 290}$ signal from the samples from site 2 were also concordant with the expected age, but the ages of the pIRIR ${ }_{50 / 290}$ signal from four samples from site 1 were underestimated.

\section{Fading-corrected (residual-subtracted) ages}

In the previous section, we showed that fading rates of the pIRIR $50 / 290$ signal were positive in all samples whereas the fading rates of the pIRIR ${ }_{200 / 290}$ signal were smaller and consistent with zero in four samples (taking account of the 2- $\sigma$ uncertainty).

To apply the fading correction, it is necessary to consider the shape of the dose-response curve. If a $D_{e}$ value 

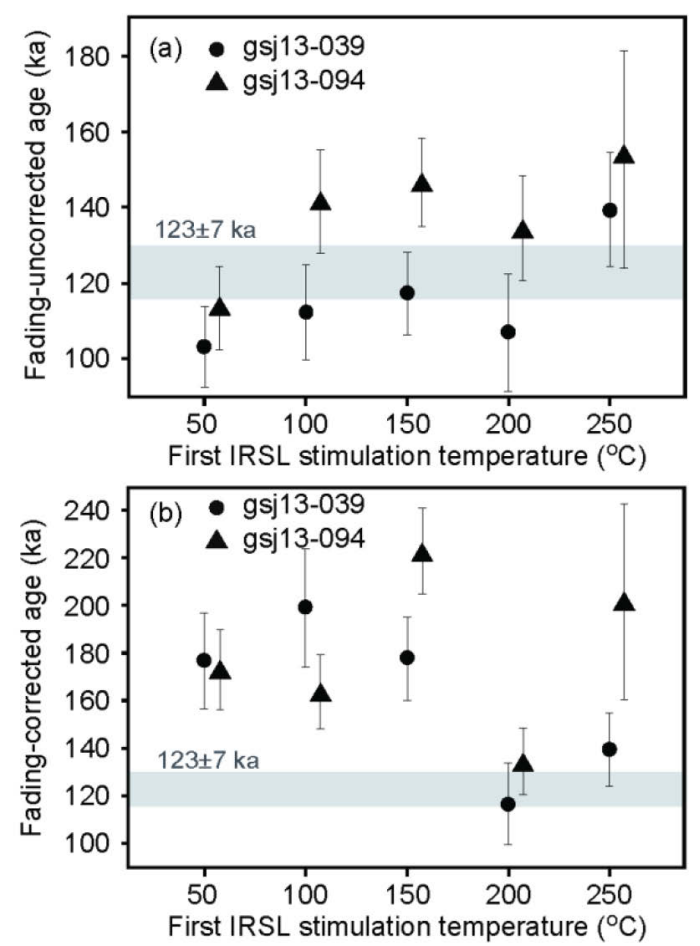

Fig. 6. (a) Uncorrected and (b) corrected pIRIR ages of gsj13-039 and gsj13-094 obtained with different first IR stimulation temperatures. The error bars show one standard error.

is within a linear region of the curve, the method of Huntley and Lamothe (2001) can be applied, but if it is on a non-linear part, the method of Kars et al. (2008) must be applied. For our samples, all natural signal to natural test dose $\left(L_{n} / T_{n}\right)$ ratios lay on a non-linear part of the doseresponse curve (Fig. 8). Therefore, the fading correction was performed by the method of Kars et al. (2008) and Kars and Wallinga (2009). This fading correction methods is based on the model of the quantum-mechanical tunnelling process proposed by Huntley (2006). The fading-corrected ages were calculated by plotting measured $\mathrm{L}_{\mathrm{n}} / \mathrm{T}_{\mathrm{n}}$ on the modelled growth curve, which was obtained from the measured dose-response curve, the the dimensionless recombination center density $\rho$ ', and the dose rate. The dimensionless value $\rho$ ' was calculated by fitting equation (7) of Huntley (2006) to the fading test results. The attempt-to-escape frequency $s$ was fixed at $3 \times 10^{15} \mathrm{~s}^{-1}$ following Huntley (2006). In the fading tests of gsj13-039 and gsj13-094 with different first IR stimulation temperatures, $\rho$ ' ranged from $(-0.42 \pm 1.15) \times 10^{-6}$ to $(2.22 \pm 0.33) \times 10^{-6}$ and from $(-0.20 \pm 0.76) \times 10^{-6}$ to $(2.24 \pm 0.40) \times 10^{-6}$, respectively. To calculate the fading-corrected ages of the pIRIR ${ }_{50 / 290}$ and pIRIR $_{200 / 290}$ signals, the average value of $\rho$ ' was used for each sampling site: $(2.12 \pm 0.26) \times 10^{-6}$ and $(0.34 \pm 0.75) \times 10^{-6}$, respectively, for site 1 (gsj13-040, gsj13-039 and gsj14$030)$, and $(1.76 \pm 0.30) \times 10^{-6}$ and $(-0.02 \pm 0.79) \times 10^{-6}$, respectively, for site 2 (gsj13-093, gsj13-094 and gsj13-095). For the pIRIR $100 / 290$, pIRIR ${ }_{150 / 290}$, and pI$\mathrm{RIR}_{250 / 290}$ signals, the $\rho$ ' values of gsj13-039 and gsj13-094 were used for the fading correction.

The corrected ages are shown in the same way as the uncorrected ages (Figs. 6b and 7). Except for the pI$\mathrm{RIR}_{200 / 290}$ signals, the corrected ages with different first IR stimulation temperatures overestimated the expected age. The corrected ages of the pIRIR $200 / 290$ signals of samples from site 1, like the uncorrected ages of the pI$\mathrm{RIR}_{200 / 290}$ signals of all samples, were concordant with the expected age (Fig. 7). On the other hand, the corrected ages of the pIRIR ${ }_{50 / 290}$ signals from all samples were always older than the expected age. The characteristic saturation dose $\left(\mathrm{D}_{0}\right)$ values of our dose-response curves were calculated based on Wintle and Murray (2006) (Table 3). The resultant $D_{0}$ values, generally ranging between 300 and $500 \mathrm{~Gy}$, were lower than the $\mathrm{D}_{0}$ values of pIRIR ${ }_{50 / 225}$ and pIRIR $50 / 290$ signals reported by Li et al. (2017) (500-730 Gy), which were obtained from the dose response curve to the saturation level. Though the size of the regenerative doses in this study were adequate to estimate a reliable $D_{e}$ value, these low $2 \mathrm{D}_{0}$ values were calculated from the dose-response curve which was not constructed up to saturation level. Therefore, to estimate a reliable corrected age of the pIRIR ${ }_{50 / 290}$ signal, the dose-response curve used for the fading correction should have been extended to saturation level.

\section{Discussion}

In this study, both fading-uncorrected and -corrected pIRIR $_{200 / 290}$ ages in site 1 were shown to be in agreement with the expected age. When we compared the uncorrected and corrected pIRIR ${ }_{200 / 290}$ ages, the corrected ages showed a much narrower age cluster around the expected age of $123 \pm 7 \mathrm{ka}$, presumably because of a small fading influence. We conclude that the fading-corrected pIRIR ${ }_{200 / 290}$ ages are most suitable, if a positive $\rho$ ' value is calculated.

The fading-corrected and -uncorrected ages of the pIRIR $_{200 / 290}$ signals of our terrigenous samples (gsj13-040 and gsj13-093) were $81 \pm 8 \mathrm{ka}$ and $86 \pm 8 \mathrm{ka}$, respectively, whereas the corrected ages of the samples from the subtidal facies ranged from $116 \pm 11$ ka to $136 \pm 15 \mathrm{ka}$. The field evidence showed that the terrigenous sediments accumulated after the deposition of the subtidal facies and were separated from them by an erosional surface. These ages indicate that the terrigenous sediment was deposited during MIS 5a. In the samples from the subtidal facies, we found no systematic stratigraphic trend of the pIRIR ${ }_{200 / 290}$ ages. This concentration of ages of the pIRIR ${ }_{200 / 290}$ signal is similar to previous results from the Oga Peninsula for the pIRIR $50 / 225$ signal (Thiel et al. 2015). The mean pIRIR $200 / 290$ ages from the subtidal facies of site 1 and site 2 were calculated to be $126 \pm 3 \mathrm{ka}$ and $132 \pm 2 \mathrm{ka}$, respectively. 
Fading-uncorrected pIRIR50/290 age

Fading-corrected pIRIR ${ }_{50 / 290}$ age

A Fading-uncorrected pIRIR $200 / 290$ age

$\triangle$ Fading-corrected $\mathrm{pIRIR}_{200 / 290}$ age

Site 1

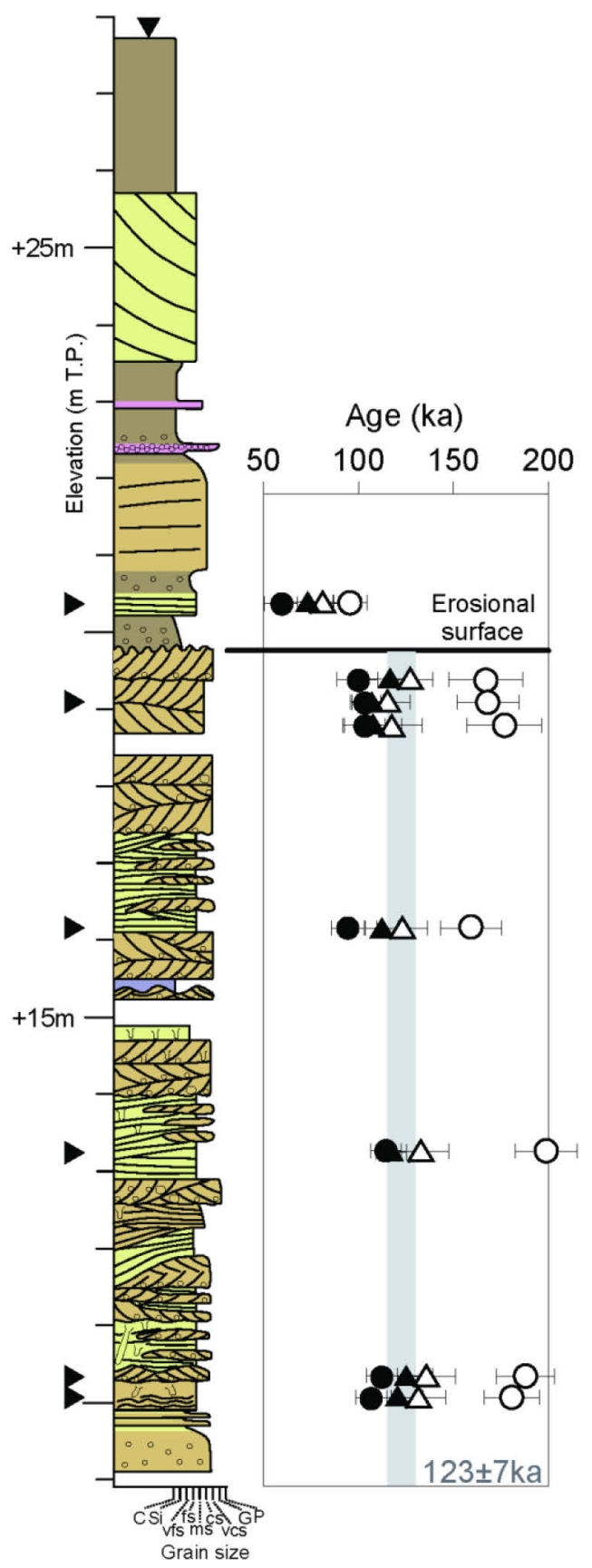

Site 2

$+30$

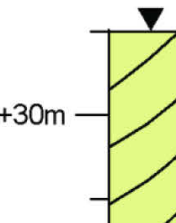

ฉ?

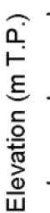

Age (ka)

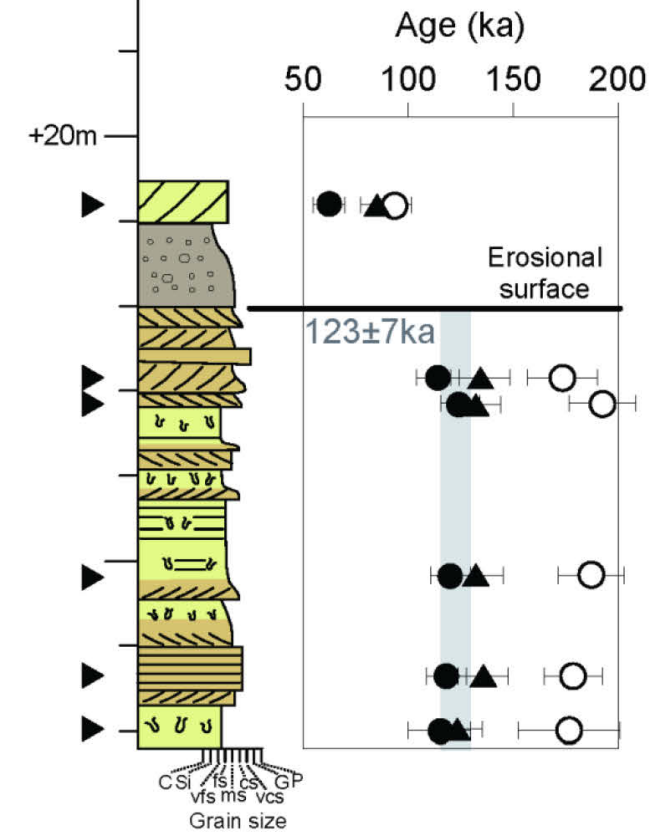

Fig. 7. Columnar sections as in Fig. 2. For sites 1 and 2, the fading-uncorrected and-corrected ages of the pIRIR50/290 and pIRIR200/290 signals are shown with one standard error. For site 2, the fading corrected ages of pIRIR200/290 signals were not calculated because the average $\rho^{\prime}$ value was lower than zero. For each site, the vertical gray bar shows the expected age range. T.P. (Tokyo Peil) is the standard datum for elevation measurements in Japan. 


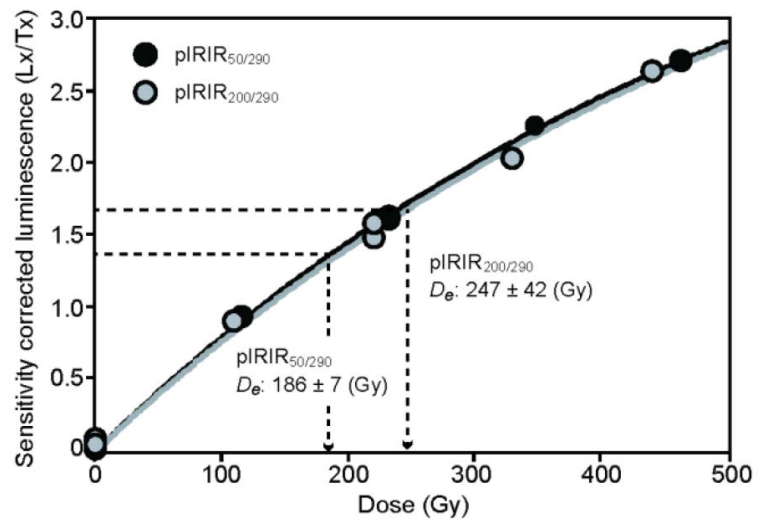

Fig. 8. Typical dose-response curve for the pIRIR $50 / 290$ and $p / R I R_{200 / 290}$ signals of sample gsj13-039.

\section{CONCLUSION}

The pIRIR dating protocol was applied to marine terrace deposits from the last interglacial on the Kamikita coastal plain, northeastern Japan. To calculate fadinguncorrected ages, the residual dose that was obtained by bleaching of a modern beach sample for $800 \mathrm{~h}$ in a solar simulator was subtracted from the $D_{e}$ of each sample. With regard to the stability of the pIRIR signal, the g-values decrease as a function of first IR stimulation temperature; from $2 \% /$ decade at $50^{\circ} \mathrm{C}$ to near zero for the pIRIR $_{200 / 290}$ and pIRIR $250 / 290$ signals. For site 1, the fading-corrected ages of the pIRIR $200 / 290$ signals showed a much narrower age cluster around the expected age of MIS 5e; the average corrected age $( \pm 1$ standard error) was $126 \pm 3 \mathrm{ka}$. On the other hand, for site 2, the fading correction was not necessary because the average $\rho$ ' value was lower than zero and the signal was stable; the average uncorrected age was $132 \pm 2 \mathrm{ka}$. We conclude that the pIRIR $200 / 290$ protocol is most suitable for determining reliable ages of marine terrace deposits of the Kamikita plain. This robust dating protocol can be further applied to determine the ages of not only terraces formed during substages of MIS5 $(5 \mathrm{a}, 5 \mathrm{c})$ but also those of older marine terraces, for which age evidence is limited.

\section{ACKNOWLEDGMENTS}

We thank Dr. Georgina King for valuable comments, which helped to improve our paper. This research project was conducted as regulatory supporting research funded by the Secretariat of the Nuclear Regulation Authority, Japan.

\section{REFERENCES}

Aitken MJ, 1985. Thermoluminescence dating. Academic Press, London.

Aitken MJ, 1998. An Introduction to Optical Dating. Oxford, Oxford University Press: 267pp.

Aoki K, 2008. Revised age and distribution of $c a .87$ ka Aso-4 tephra based on new evidence from the northwest Pacific Ocean. Quaternary International 178: 10-118, DOI 10.1016/j.quaint.2007.02.005.

Aoki K, Irino T and Oba T, 2008. Late Pleistocene tephrostratigraphy of the sediment core MD01-2421 collected off the Kashima coast, Japan. The Quaternary Research 47: 391-407 (in Japanese, English abstract).

Auclair M, Lamothe M and Huot S, 2003. Measurement of anomalous fading for feldspar IRSL using SAR. Radiation Measurements 37: 487-492, DOI 10.1016/S1350-4487(03)00018-0.

Balescu S and Lamothe M, 1994. Comparison of TL and IRSL age estimates of feldspar coarse grains from waterlain sediments. Quaternary Science Reviews 13: 437-444, DOI 10.1016/02773791(94)90056-6.

Barreto AMF, Bezerra FHR, Sugio K, Tatumi SH, Yee M, Paiva RP and Munita CS, 2002. Late Pleistocene marine terrace deposits in northeastern Brazil: sea-level change and tectonic implications. Palaeogeography, Palaeoclimatology, Palaeoecology 179: 57-69, DOI 10.1016/S0031-0182(01)00408-4.

Bell WT, 1980. Alpha dose attenuation in quartz grains for thermoluminescence dating. Ancient TL 12: 4-8.

Buylaert JP, Murray AS, Thomsen KJ and Jain M, 2009. Testing the potential of an elevated temperature IRSL signal from K-feldspar. Radiation Measurements 44: 560-565, DOI 10.1016/j.radmeas.2009.02.007.

Buylaert JP, Thiel C, Murray AS, Vandenberghe DAG, Yi S and Lu H, 2011. IRSL and post-IR IRSL residual doses recorded in modern dust samples from the Chinese loess plateau. Geochronometria 38: 432-440, DOI 10.2478/s13386-011-0047-0.

Buylaert JP, Jain M, Murray AS, Thomsen KJ, Thiel C and Sohbati R, 2012. A robust feldspar luminescence dating method for Middle and Late Pleistocene sediments. Boreas 41: 435-451, DOI 10.1111/j.1502-3885.2012.00248.x.

Buylaert JP, Murray AS, Gebhardt AC, Sohbati R, Ohlendorf C, Thiel C, Wastegard S, Zolitschka B and The PASADO Science Team, 2013. Luminescence dating of the PASADO core 5022-1D from Laguna Potrok Aike (Argentina) using IRSL signals from feldspar. Quaternary Science Reviews 71: 70-80, DOI 10.1016/j.quascirev.2013.03.018.

Buylaert JP, Yeo E-Y, Thiel C, Yi S, Stevens T, Thompson W, Frechen $\mathrm{M}$, Murray A and Lu H, 2015. A detailed post-IR IRSL chronology for the last interglacial soil at the Jingbian loess site (northern China). Quaternary Geochronology 30: 194-199, DOI 10.1016/j.quageo.2015.02.022.

Choi JH, Murray AS, Jain M, Cheong CS and Chang HW, 2003. Luminescence dating of well-sorted marine terrace sediments on the southeastern coast of Korea. Quaternary Science Reviews 22: 407421, DOI 10.1016/S0277-3791(02)00136-1.

Clifton HE, 2006. A reexamination of facies models for clastic shorelines, In: Posamentier H. W., Walker R. G. (Eds.), Facies Models Revisited. Society for Sedimentary Geology, Oklahoma, SEPM Special Publication 84: 293-337.

Cummings DI, Dumas S and Dalrymple RW, 2009. Fine-grained versus coarse-grained wave ripples generated experimentally under largescale oscillatory flow. Journal of Sedimentary Research 79: 8393, DOI 10.2110/jsr.2009.012.

Duller GAT, 1992. Luminescence chronology of raised marine terraces, South-West North Island, New Zealand. A thesis submitted in fulfilment of the award of the degree of Doctor of Philosophy at the University of Wales, 1-147.

Duller GAT, 2016. Analyst v4.31.9 user manual, 88p.

Fruergaard M, Andersen TJ, Nielsen LH, Johannessen PN, Aagaard T and Pejrup M, 2015. High-resolution reconstruction of a coastal 
barrier system: impact of Holocene sea-level change. Sedimentology 62: 928-969, DOI 10.1111/sed.12167.

Ganzawa Y and Ike M, 2011. SAR-RTL dating of single grain of volcanic quartz from the late Pleistocene Toya Caldera. Quaternary Geochronology 6: 42-49, DOI 10.1016/j.quageo.2010.07.001.

Guérin G, Mercier N and Adamiec G, 2011. Dose-rate conversion factors: update. Ancient TL 29: 5-8.

Huntley DJ, 2006. An explanation of the power-law decay of luminescence. Journal of Physics: Condensed Matter 18: 1359-1365, DOI 10.1088/0953-8984/18/4/020.

Huntley DJ and Baril MR, 1997. The K content of the K-feldspars being measured in optical dating or in thermoluminescence dating. Ancient TL 15: 11-13.

Huntley DJ and Lamothe M, 2001. Ubiquity of anomalous fading in Kfeldspars and the measurement and correction for it in optical dating. Canadian Journal of Earth Science 38: 1093-1106, DOI 10.1139/e01-013.

Huntley DJ, Godfrey-Smith DI and Haskell EH, 1991. Light-induced emission spectra from some quartz and feldspars. Nuclear Tracks and Radiation Measurements 18: 127-131, DOI 10.1016/13590189(91)90104-P.

Jacobs Z, 2008. Luminescence chronologies for coastal and marine sediments. Boreas 37: 508-535, DOI $10.1111 / \mathrm{j} .1502-$ 3885.2008.00054.x.

Kars RH and Wallinga J, 2009. IRSL dating of K-feldspar: Modeling natural dose response curve to deal with anomalous fading and trap competition. Radiation Measurements 44: 594-599, DOI 10.1016/j.radmeas.2009.03.032.

Kars RH, Wallinga $\mathrm{J}$ and Cohen KM, 2008. A new approach towards anomalous fading correction for feldspar IRSL dating - test on samples in field saturation. Radiation Measurements 43: 786-790, DOI 10.1016/j.radmeas.2008.01.021.

Kars RH, Busschers FS and Wallinga J, 2012. Validating post IR-IRSL dating on K-feldspars through comparison with quartz OSL ages. Quaternary Geochronology 12: 74-86, DOI 10.1016/j.quageo.2012.05.001.

Kars RH, Reimann T, Ankjærgaard C and Wallinga J, 2014. Bleaching of the post-IR IRSL signal: new insights for feldspar luminescence dating. Boreas 43: 780-791, DOI 10.1111/bor.12082.

Koike K and Machida H, 2001. Atlas of Quaternary Marine Terraces in the Japanese Islands. University of Tokyo Press, ISBN 4130607359 (in Japanese).

Kuwabara, 2009. Environmental change and its correlation to terraces based on phytolith assemblage of tephra-soil succession after the latter half of the middle Pleistocene drilled at the Kamikita Plain, NE Japan. The Quaternary Research 48: 405-416 (in Japanese, English abstract).

Li B and Li SH, 2011. Luminescence dating of K-feldspar from sediments: A protocol without anomalous fading correction. Quaternary Geochronology 6: 468-479, $\quad$ DOI 10.1016/j.quageo.2011.05.001.

Li B and Li SH, 2012. A reply to the comments by Thomsen et al. on "Luminescence dating of K-feldspar from sediments: A protocol without anomalous fading correction". Quaternary Geochronology 8: 49-51, DOI 10.1016/j.quageo.2011.10.001.

Li B, Roberts RG, Jacobs Z and Li S-H, 2014. A single-aliquot luminescence dating procedure for K-feldspar based on the dosedependent MET-pIRIR signal sensitivity. Quaternary Geochronology 20: 51-64, DOI 10.1016/j.quageo.2013.11.001.

Li Y, Tsukamoto S, Frechen M and Gabriel G, 2017. Timing of fluvial sedimentation in the Upper Rhine Graben since the Middle Pleistocene: constraints from quartz and feldspar luminescence dating. Boreas, 10.1111/bor.12266.

Lisiecki L and Raymo ME, 2005. A Pliocene-Pleistocene stack of 57 globally distributed benthic $\delta^{18} \mathrm{O}$ records. Paleoceanography 20: PA1003, DOI 10.1029/2004PA001071.

Machida H and Arai F, 2003. Atlas of Tephra in and Around Japan. University of Tokyo Press, ISBN 4130607456 (in Japanese).

Matsu'ura T, Furusawa A, Shimogama K, Goto N and Komatsubara J, 2014. Late Quaternary tephrostratigraphy and cryptotephrostratigraphy of deep-sea sequences (Chikyu C9001C cores) as tools for marine terrace chronology in NE Japan. Quaternary Geochronology 23: 63-79, DOI 10.1016/j.quageo.2014.06.001.

Mejdahl V, 1979. Thermoluminescence dating: beta-dose attenuation in quartz grains. Archaeometry 21: 61-72, DOI 10.1111/j.14754754.1979.tb00241.x.

Miyauchi T, 1985. Quaternary crustal movements estimated from deformed terraces and geologic structures of the Kamikita coastal plain, Northeast Japan. Geographical Reviews of Japan 58: 492515. (in Japanese, English abstract)

Miyauchi T, 1987. Quaternary Tectonic Movements of the Kamikita Coastal Plain, Northeastern Japan. Geographical Review of Japan 60: 1-19.

Murray AS and Funder S, 2003. Optically stimulated luminescence dating of a Danish Eemian coastal marine deposit: a test of accuracy. Quaternary Science Reviews 22: 1177-1183, DOI 10.1016/S0277-3791(03)00048-9.

Pascucci V, Sechi D and Andreucci S, 2014. Middle Pleistocene to Holocene coastal evolution of NW Sardinia (Mediterranean Sea, Italy). Quaternary International 328-329: 3-20, DOI 10.1016/j.quaint.2014.02.018.

Pawley SM, Bailey RM, Rose J, Moorlock BSP, Hamblin RJO, Booth SJ and Lee JR, 2008. Age limits on Middle Pleistocene glacial sediments from OSL dating, north Norfolk, UK. Quaternary Science Reviews 27: 1363-1377, DOI 10.1016/j.quascirev.2008.02.013.

Pedoja K, Dumont JF, Lamothe M, Ortlieb L, Collot J-Y, Ghaleb B, Auclair M, Alvarez V and Labrousse B, 2006a. Plio-Quaternary uplift of the Manta Peninsula and La Plata Island and the subduction of the Carnegie Ridge, central coast of Ecuador. Journal of South American Earth Sciences 22: 1-21, DOI 10.1016/j.jsames.2006.08.003.

Pedoja K, Ortlieb L, Dumont JF, Lamothe M, Ghaleb B, Auclair M and Labrousse B, 2006b. Quaternary coastal uplift along the Talara Arc (Ecuador, Northern Peru) from new marine terrace data. $\mathrm{Ma}$ rine Geology 228: 73-91, DOI 10.1016/j.margeo.2006.01.004.

Prescott JR and Hutton JT, 1994. Cosmic ray contributions to dose rates for luminescence and ESR dating: large depths and long-term time variations. Radiation Measurements 23: 497-500, DOI 10.1016/1350-4487(94)90086-8.

Reimann T, Notenboom PD, De Schipper MA and Wallinga J, 2015. Testing for sufficient signal resetting during sediment transport using a polymineral multiple-signal luminescence approach. Quaternary Geochronology 25: 26-36, $\quad$ DOI 10.1016/j.quageo.2014.09.002.

Roberts HM, 2012. Testing Post-IR IRSL protocols for minimising fading in feldspars, using loess with independent chronological control. Radiation Measurements 47: 716-724, DOI 10.1016/j.radmeas.2012.03.022.

Shirai M, Tada R and Fujioka K, 1997. Identification and Chronostratigraphy of Middle to Upper Quaternary Marker Tephras Occurring in the Anden Coast Based on Comparison with ODP Cores in the Sea of Japan. The Quaternary Research 36: 183-196 (in Japanese, English abstract).

Shiraishi T, Arai F and Fujimoto Y, 1992. Discovery of Aso-4 and Drift Pumice of Aso-4 Pyroclastic Flow and Sambe-Kisuki Pumice Fall Deposits in the Upper Quaternary of the Oga Peninsula, Akita Prefecture, Northeast Honshu, Japan. The Quaternary Research 31: 21-27 (in Japanese, English abstract).

Sohbati R, Murray AS, Buylaert JP, Ortuño M, Cunha PP and Masana E, 2012. Luminescence dating of Pleistocene alluvial sediments affected by the Alhama de Murcia fault (eastern Betics, Spain) - a comparison between OSL, IRSL and post-IR IRSL ages. Boreas 41: 250-262, DOI 10.1111/j.1502-3885.2011.00230.x.

Tamura T, Nanayama F, Saito Y, Murakami F, Nakashima R and Watanabe K, 2007. Intra-shoreface erosion in response to rapid sea-level fall: depositional record of a tectonically uplifted strand plain, Pacific coast of Japan. Sedimentology 54: 1149-1162, DOI 10.1111/j.1365-3091.2007.00876.x.

Tanaka K, Hataya R, Spooner NA, Questiaux DG, Saito Y and Hashimoto T, 1997. Dating of marine terrace sediments by ESR, TL and OSL methods and their applicabilities. Quaternary Science Reviews 16: 257-264, DOI 10.1016/S0277-3791(96)00092-3. 
Thiel C, Coltorti M, Tsukamoto S and Frechen M, 2010. Geochronology for some key sites along the coast of Sardinia (Italy). Quaternary International 222: 36-47, DOI 10.1016/j.quaint.2009.12.020.

Thiel C, Buylaert JP, Murray AS and Tsukamoto S, 2011a. On the applicability of post-IR IRSL dating to Japanese loess. Geochronometria 38: 369-378, DOI 10.2478/s13386-011-0043-4.

Thiel C, Buylaert JP, Murray AS, Terhorst B, Hofer I, Tsukamoto S and Frechen M, 2011b. Luminescence dating of the Stratzing loess profile (Austria) - Testing the potential of an elevated temperature post-IR IRSL protocol. Quaternary International 234: 23-31, DOI 10.1016/j.quaint.2010.05.018.

Thiel C, Buylaert JP, Murray AS, Elmejdoub N and Jedoui Y, 2012. A comparison of TT-OSL and post-IR IRSL dating of coastal deposits on Cap Bon peninsula, north-eastern Tunisia. Quaternary Geochronology 10: 209-217, DOI 10.1016/j.quageo.2012.03.010.

Thiel C, Tsukamoto S, Tokuyasu K, Buylaert J P, Murray AS, Tanaka $\mathrm{K}$ and Shirai M, 2015. Testing the application of quartz and feldspar luminescence dating to MIS 5 Japanese marine deposits. Quaternary Geochronology 29: 16-29, DOI 10.1016/j.quageo.2015.05.008

Thomsen KJ, Murray AS, Jain M and Bøtter-Jensen L, 2008. Laboratory fading rates of various luminescence signals from feldspar-rich sediment extracts. Radiation measurements 43: 1474-1486, DOI 10.1016/j.radmeas.2008.06.002.

Thomsen KJ, Murray AS and Jain M, 2011. Stability of IRSL signals from sedimentary K-feldspar samples. Geochronometria 38: 1-13, DOI 10.2478/s13386-011-0003-z.

Walker RG and Plint AG, 1992. Wave and storm-dominated shallow marine systems, In Walker R.G. and James N.P. (Eds.), Facies Models response to Sea-Level Change. Geological Assn of Canada: $219-238$.

Wintle AG and Murray AS, 2006. A reviews of quartz optically stimulated luminescence characteristics and their relevance in singlealiquot regeneration dating protocols. Radiation Measurements 41: 369-391, DOI 10.1016/j.radmeas.2005.11.001.

Yi S, Buylaert JP, Murray AS, Lu H, Thiel C and Zeng L, 2016. A detailed post-IR IRSL dating study of the Niuyangzigou loess site in northeastern China. Boreas 45: 644-657, DOI 10.1111/bor.12185.

Zander A and Hilgers A, 2013. Potential and limits of OSL, TT-OSL, IRSL and pIRIR290 dating methods applied on a Middle Pleistocene sediment record of Lake El'gygytgyn, Russia. Climate of the Past 9: 719-733, DOI 10.5194/cp-9-719-2013. 